\title{
The Role of Education for Identity Formation Among Albanians and Serbs of Kosovo: the Application of the Difference-Blinded Approach for Establishing Citizenship Regime in a Multi-Cultural Society
}

\author{
Ardian Kastrati, MA, PhD Cand. \\ Department of Political Sciences, University of Prishtina \\ ardian.kastrati@uni-pr.edu
}

\begin{abstract}
As a result of striving accession to the EU, all states in southeast Europe have as precondition to solve inter ethnic conflicts and to balance the system in a way that makes the relations between dominant group and minorities one of the mutual respect, based upon the principle of non discrimination. In Western Balkans some of the most controversial issues in the past decade have revolved around the educational rights. The fragile society of Kosovo faces many challenges, and the system of education is just one of them. The ongoing dialogue between Serbia and Kosovo and painful process of state building often overshadows important educational issues. The educational system of Kosovo is segregated, extremely divisive and highly politicized. It is widely accepted that education has strong impact on individual's identity formation. In this context ethnicity, nationality and citizenship constitute just a few of the possible identities within the individual's self-conception being the most relevant to the relationship between citizen and the state. In the analyses of the theoretical foundations of multiculturalism the role of education in a culturally diverse society is very important for identity formation based on the concept of the citizenship as identity. By constitution Kosovo is a multicultural society but the meanings and expressions of this are contested both within the dominant Albanian majority and Serbian minority. Conceiving comprehensive discussions if Albanians and Serbs of Kosovo in the future could potentially accept to identify themselves through the citizenship of the new state before their ethnic and national based identities (cross linked with Albania respectively Serbia), it is a broad topic and beyond the scope of this paper, but for the purpose of this study the concept of the citizenship as identity is considered only in a narrower context - that of the role of education in identity formation.
\end{abstract}

Keywords: education, identity, recognition, citizenship, multiculturalism.

\section{Introduction}

The road to an active and diversified civil society can be especially long and arduous where the legacies of communism are reinforced by the deliberate manipulation of nationalism. Kosovo illustrates well the important role that nationalism and myths play in shaping human behavior. The negative nationalism that characterized the Balkans during the 1990s promoted authoritarianism, which fostered an intolerant political culture. The Serbian myth known as Kosovo battle fought in 1389 marked the beginning of the collapse of ex-Yugoslavia. The history of myths was served to younger generations for decades through school curriculums and state media. Hatred and segregation was reflected in every segment of Kosovo public system of education, affecting the joint education system, which had been in place since the World War II.

Historically, school curriculums were designed from outside of Kosovo. History falsification and the impact of myths throughout school curriculums in Kosovo have had a serious impact on the education of new generations. Since the fall of communism in the 90s the Western Balkans had been undergoing fundamental and multiple transformations. 'These transformations are complex in their nature and difficult to explain by a single paradigm or model. Such a complex transformation, where democratization and transition take place in conjunction with nation-and state-building and European integration, usually comes at the expense of a truncated picture of the region' (Jano, 2008).

During the complex process of transformation the legacies of communism and nationalism in Kosovo had a crucial role in designing the educational system in Kosovo. This paper aims to explore the impact of education for the ethnic and national identity formation of both Albanians and Serbs in Kosovo, to the extent that such alternative is considered threatening for the future of Kosovo and its EU Integration process. The study presents the legacies of nationalism and communism in 
shaping the human and political behavior by discussing historical and current levels of segregation in Kosovo's system of education.

\subsection{The history and development of the Kosovo's education system}

\subsection{Education for ethnic Albanians during the Ottoman Empire and Serbia's rule}

Kosovo cannot be proud for the tradition on education during the 500 year occupation under Ottoman Empire and the period under Serbia's rule until the World War II. Living most of the time in the circumstances of discrimination, repression and wars it was difficult for the Albanian majority population in Kosovo to establish schools in their own language. The first document in written Albanian dates from the 16th century. The first written document of the modern Albanian language is of the year 1462. The book "Meshari" by Gjon Buzuku was published in 1555.

Under the Ottoman Empire rule no Albanian schools were allowed to be established independently. Institutionally only the religious schools were operational under the control of the empire through their local representatives. Educational battles of Albanians continued but it was difficult to set up a system of schools in which there would be minimum ottoman impact." Clandestine efforts aimed at promoting the Albanian sense of nationhood in religious schools were taking place alongside the institutional struggle for the Albanian schools. A demand for Albanian language schooling was voiced in the parliament by Albanian members of Xhemijet, the party representing Muslims in Sandjak, Kosovo and Macedonia. However they also developed an underground activity and helped to revive secret schools. Secret schools were entirely secular, while secular and religious teaching content was combined in the religious schools. Albanian nationalist from Kosovo staunchly opposed the education of Albanians in Serbian schools, for as Hasan Prishtina said; they teach something other then what we wish our lads to learn." (Kostovicova, 2005). Albanian culture and Albanian nationhood was mainly developed through Islamic institutions like mektebs, medreses and tekkes.

There was not either a proper and institutional organized system of education in Kosovo in between two world wars. Serbian influence in those rarely established schools in which Albanians could attend classes was prevailing. Some of the attempts to establish schools in Albanian did not survive and after the establishment of some schools under the system of Serb, Croat and Slovene Kingdom it was almost difficult to see Albanians from Kosovo having access in them. Although there were few schools established, they were all in Serbian and on the other hand denying to Albanians to establish their schools in their own language. This contributed to their illiteracy until the World War II was finished.

\subsection{System of education for Albanians in Yugoslavia (1945-1974)}

After WWII the education system for the majority Albanian population did not substantially improve. Between 1946- 1968 today's Kosovo was officially a district called Kosovo and Metohija (Constitution of PFRY-1946). With the new constitution of 1963 the Peoples Federative Republic of Yugoslavia (PFRY) became the Socialist Federative Republic of Yugoslavia (SFRY) and Kosovo gained the status of Autonomous Province while Albanians from the notion "national minority" were defined into "nationality". Regardless of these changes there was no essential improvement of the quality of life for Albanians in Kosovo. In the years to come, Kosovo-Albanians were marked by repression and discrimination in almost all aspects of public life. Following constitutional amendments initiated by the federation and coupled with the student demonstrations of 1968, the treatment of the Albanian majority population of Kosovo started to move in a positive direction. In this context mass education for Albanians in socialist Yugoslavia saw some progress. One of the main reasons was the fall of Aleksandar Rankovic, a high Serbian official of secret police who was well known for his repressive policies against Albanians. 'The fall of Rankovic came after a failure of his behind-the-scenes attempt to overthrow Tito and re-establish a Serb dominated centralized state similar to the one that prevailed during the period 1948- 63 1965.' (Lukic, 1996).

After Rankovic's fall, Serbian law began to devolve some control over educational issues to Kosovo; however, this still did not allow young Albanian intellectuals to independently develop their national culture. During this period education became one of the top priorities of Kosovo's Communist Party, noted by a qualitative advance in the years to come. 'The opening of the University of Pristina in 1970, with Serbian and Albanian languages enjoying equal standings, paved the way for mass education of the Albanian student' (Kostovicova, 2005). This situation was better when compared to the Rankovic era, but despite these improvements, the overall situation in Kosovo did not substantially improve. Being aware of that, 
Yugoslav authorities tried to soften the standard of living in the province. Substantial investments in the province, mostly in mines, energy, and large automated industries, created few jobs and did little to reduce unemployment. Unemployment remained high.

\subsubsection{Education system between 1974-1981}

The spread of Albanian education reached its peak with the new constitution of the SFRY in 1974. The new Constitution of 1974 upgraded Kosovo's legal status. Two constituent parts of Serbia (Kosovo and Vojvodina) were established as autonomous provinces but also with their right as federal units. The 1974 Constitution provided full equality to republics and autonomous provinces, allowing participation in the new collective presidency. This consisted of 9 members: the President of Yugoslavia, representatives from the six republics and those from the autonomous provinces. 'The 1974 constitution formally defines the autonomous provinces as constituent members of the federation. 65 Kosovo and Vojvodina are granted de facto the status of sovereign republics in almost all respects, differing from the other six republics insofar as they are not granted the right to secede from the federation.' (Mertus, 1999). The years $1974-1980$, marked the 'late Titoism' period. This period allowed Albanians in Kosovo space to develop their cultural, political and national identity within the new education system. Despite this advance, there were consistent problems, as many federal mechanisms were in place to keep the education within the Yugoslav ideological contexts. Serbian authorities constantly fought against the idea of having an independent system of education for Kosovo-Albanians, accusing Albanians of developing the socalled irredentism and separatism movement in Kosovo schools. The Serbian government insisted that Kosovo returned to the pre 1974 situation. In order to do this, the Government had to cause obstructions at the federal level. "With the constitutional devolution of 1974, republics and provinces 66 became masters of their educational policy and decided on the network and structure of the schools and curricula. However, general guidelines for the educational policy were subject to an agreement in the federal level.' (Kostovicova, 2005). In order to achieve its political aims, Serbian authorities insisted upon a return of its legal control over Kosovo schools and the university. This led to a consistent confrontation between the authorities and ethnic Albanians over the Kosovo education system. Many Albanian political prisoners came from Kosovo schools and the university. At that time, Kosovo had the highest number of the political prisoners at the federal level. 'From 1971 to 1981, public expression of political dissent was suppressed in all parts of Yugoslavia, but the greatest percentages of political prisoners were Kosovo Albanians." (Mertus, 1999). After Tito's death and between 1981-1989, several officials planned on how to strengthen the power of the Yugoslav 67 federation. These attempts were developed in continuity from Belgrade, as Serb leaders saw their chance to take power from the other republics at the federal level. Yugoslavia became a fragile society full of animosities and mixed feelings, starting with those who predicted injustice coming back for them, to those who were encouraging ethno-nationalist leaders to go ahead with their plans.

\subsubsection{Abrogation of Kosovo's autonomy (1989-1999)}

Milosevic's policy to reconquest Kosovo had begun in 1988, with a powerful propaganda campaign launched against Albanian 'nationalists and separatists'. He prepared the situation on the ground by raising tensions on his visits to Kosovo by feeding animosity between the Serbian population and their Albanian neighbors. The promotion of Serbian hegemony started in Kosovo in 1988. Over a four -week period during the February and March of 1989, Milosevic crushed Kosovo's autonomy by initiating violent demonstrations that claimed the lives of over one hundred Albanians (Sell, 2003). Simultaneously, he began to prepare his tactics in political and legal contexts. In meetings with communist chiefs of the other Yugoslav republics Milosevic made it clear that he intended to revoke Kosovo's autonomy. In order to do that legally, he had first to amend Constitution of Republic of Serbia. According to 1974 Constitution, amendments related to the status of Kosovo and Vojvodina as autonomous provinces could not be passed in Serbia's assembly without prior vote of both Kosovo and Vojvodina assemblies.

Determined against Milosevic's initiative the majority of Albanian delegates of the Kosovo assembly refused to vote proposed amendments. Feeling under pressure and intimidated by the presence of the Serbian police who had surrounded the Kosovo Assembly building with special police units, and tanks, they were unable to stop the passage of this act. 'In a state of emergency, without the required quorum, without counting votes and by voting of persons that were found in the hall but who were not delegates, the Serb president of the Assembly of Kosova, proclaimed on March 23, 1989 the approval 
of the constitutional amendments.' (Bieber, Daskalovski, 2003). It can be argued that any act passed under a threat, denying the real will of the people, can and should be void. Therefore the decision of the assembly of Serbia, which passed on March 28, 1989, was considered invalid by Albanian delegates. As a response, on 2nd of July 1990 the Albanian delegates, comprising of the majority of Kosovo's Assembly approved the declaration of independence of Kosova. 'Being denied from Serbian police to access the assembly building this act was passed at the gates outside the assembly building. This preceded the Constitution of the Republic of Kosovo, which was approved on September 7, 1990.' (Bieber, Daskalovski 2003). Abrogation of Kosovo's autonomy and living under the Milosevic's repressive regime was unacceptable for Kosovo Albanians. Consequently, they started to organize the socalled 'civil resistance' against the Milosevic's regime.

\subsubsection{Albanian 'parallel' system of education}

One of the most repressive actions of Milosevic's regime was the dismissal of all Albanian education personnel. Albanians rejected the Serbian curriculum that had been adopted by the Serbian Educational Council. This was the pretext for the regime to use Serbian police forces to forbid Albanian access to their schools. Thousands of Albanian professors and students from primary to university level were dismissed, only Serbs were allowed to have access to the public schools. The 'Serbianization' of the Kosovo police force was a strong clue as to the future look of Kosovo's schools. This repressive situation pushed the Albanian community to look for other alternatives. As a form of their civil resistance to Serbia, Albanians created their own system of education out of the public facilities. 'Self-financed post autonomy graduates in Kosovo were the generations of the Kosovo Republic. They no longer studied the people's heroes who had fought for 'brotherhood and unity' of Yugoslav nations and nationalities' (Schwandner -Sievers and Jurgen Fischer, 2002).

Education was organized in private houses and garages, especially for high schools and University of Prishtina (UP). New curricula were enacted with an aim to promote the Albanian national identity. 'This came to be known as parallel education. It was the cause that galvanized the entire Albanian community in Kosovo into action, triggering its unprecedented homogenization. Albanian parallel education in Kosovo emerged as an embodiment of the Albanian civil and peaceful resistance, and an argument used to prove the existence of the Albanian independent state in Kosovo' (Kostovicova, 2005). Schools and the University were the most important institutions where the Serb and Albanian communities mixed to some degree, before 1990 in Kosovo.

After the Albanians were forced into a completely separate social life, walls of division appeared between the two communities, and Kosovo developed two extremely segregated systems of education, which have remained almost the same into the present. Albanians contributed to this system by giving their houses free of charge for Kosovo schools and paying taxes to Kosovo's Government in exile from 1991 to 1998 in order to maintain the parallel educational system. 'Attempts to convene an Albanian parliament in Kosovo or establish a police force were thwarted, whilst the Government of the self proclaimed Kosovo Republic had to seek safety in exile' (Waller, Drezov, Gökay, 2001). Parallel institutions became a point of national pride and motivation for further solidification among Albanians for their statehood. The launch of the parallel system was also a gesture by Albanians to show to the international community 'the independent Kosovo'. LDK leadership used this model of success as an important symbol and proof of Albanian statehood in Kosovo. 'One Albanian analyst suggested that Ibrahim Rugova should more accurately be called "President of the parallel schools of Kosovo" than 'The President of Republic of Kosovo', his official title. This very same education system, in private house, inadequate cellars and garages, helped sustain the metaphor of Kosovo as a prison' (Waller, Drezov, Gökay, 2001). Because of the development and continuity of the educational and health care system after 1991 and some other aspects of civil resistance, K-Albanians were able to maintain to some degree a parallel political sphere independent of Serbia. As outlined above civil society in Kosovo emerged and took its form within the context of non-violent civil resistance led from LDK and Mr.Rugova. 'The nonviolence movement became part of the modern Albanian identity that drew together both village patriarchs and urban intelligentsia in a common effort to avoid a tragedy' (Clark, 2000). Certain strategic goals were clear as to why Albanians named their movement as non-violent and peaceful: first, to avoid offering a pretext for Serbian police and military forces for brutal interventions (although there was a systematic repression of Albanian civilians during 1990s), second, the importance of involving international support both in political and humanitarian aspect, and third, to strengthen the limited social space by fulfilling basic social needs for Albanian population, such as medical care and education. Non-violent civil resistance represents the first phase of the development of the civil society in Kosovo (Clark, 2000). While in much of the communist bloc, peaceful transition from totalitarian and one-party rule to plural and democratic 
regimes, buttressed by civil society contributions, was made possible, Kosovo's civil society experienced a different kind of development (Khdr, 2008).

\subsection{History of partition from opposing perspectives and its effects on the state building and EU integration processes}

Parallel system of education for Albanians on one side and Serbia's state curriculums imposed for Kosovo Serbs on the other side during the 1990's have had a direct impact in establishing a completely segregated and divisive education system in Kosovo after the war of 1998-1999.

Today Kosovo has two parallel systems of education, the dominant education system organized by Kosovo institutions attended from the Albanian majority and some non-Serb minorities, and education institutions funded by Serbian Government attended from Serbs and some other minorities. Nowhere in Europe is there such segregation in schools as in Kosovo. Kosovo institutions and international community have failed to offer an integrated and homogenous school curriculum both for Kosovo Albanians and Serbs. On the other side, minority Serbs are constantly prevented from Belgrade for their minimum integration in Kosovo's education system. Consequently, the formation of ethnically based identity among younger generations remains a natural alternative and as a result both ethnic and national identities play important roles in guiding their political behavior.

History of education has played a particularly important role in communicating the national narrative to younger generations and fostering the development of those identities. Today, both sides teach their children about Kosovo's history from two completely opposing perspectives, each country's national narrative vilifies the other producing mutual hatred among younger generations from both sides.

This model of teaching the national history through two different systems of education within Kosovo's territory promotes and reinforces the national and ethnical identity among the new generations from both sides. Serbs neither want nor see a need to participate in designing school curriculums considering them to belong to self-declared state of Kosovo. Albanians governing with the majority of educational institutions in the country prefer to implement curriculum not always in the spirit of the Constitution of Kosovo which defines Kosovo as multiethnic state. This kind of rejection from both sides produces what is called the stateness problem by harming the state-building process. Simultaneously Kosovo's EU integration perspectives that should encourage and promote tolerance between different ethnic groups in a multicultural society are harmed - elements those guaranteed by the Constitution of the Republic of Kosovo based on the concept of the citizenship as identity. Consequently, number of individuals who could potentially identify themselves with the new state of Kosovo based on the values of the citizenship as identity is less compared to the ethnocentric individuals who identify strongly with their ethnicity and maintain a belief that only their ethnic group is centrally important. Many of us have witnessed that ethnocentric arguments have justified many horrific events in the history of Balkans, including genocide and ethnic cleansing.

Therefore the failure of democratization in Kosovo among other reasons can be attributed to the system of education with full of contradictions where the strength of the national and ethnic identity prevails. As more ethnically divided schools are, the more difficult it is for democratization to succeed and even more difficult to link Albanians and Serbs with the new state of Kosovo.

Given the foregoing discussion, one can ask what kind of roles should education play in a multicultural society that has yet to achieve its ideals and if it is possible at all to recognize and develop a positive bicultural identity for minority Serbs in the future?

\section{Conclusions}

Kosovo and Serbia delegations during the dialogue in Brussels have reached agreement on mutual recognition of diplomas in both countries. It is only an agreement of technical nature allowing those with a diploma from both sides to apply for a job and potentially work in these two respective countries in the future. In fact the ongoing dialogue between Serbia and 
Kosovo and painful process of state building overshadows the core of the educational issues discussed in this paper. The educational system of Kosovo remains segregated and extremely politicized.

The issue here is not of doing reforms in legislation by designing and redesigning policies and strategies for various levels of the system of education. As Terrice Bassler describes, the context of education in South East Europe is diverse and full of contradictions. There are breakthroughs and occasional triumphs, such as peace agreement or an election that heralds a better time, a national education reform process launched or legislation passed, a new project or program approved, a textbook or training delivered. There are twist and turns in the Ministry of Education-or an entire Government, for that matter (Bassler, 2005). Kosovo makes no exception in doing similar experiments sponsored from the international community and local institutions on behalf of reforming education system in Kosovo.

In fact the problem doesn't rely in such reforms. The essence of the problem is that the education in continuity was conducted in extreme nationalist spirit impacting and strengthening ethnic and nationalist identity among younger generations, it therefore cannot be changed with the sort of reforms that are more of a technical, formal and of a quantitative nature. This problem as pointed out in this paper is rooted deeply after the World War II, during the Yugoslav times, continuing under the regime of Milosevic and the concept survived and was even incarnated under UNMIK administration and now in independent Kosovo. This is mostly because the international community wrongly invested in improving relations between the Albanian majority and the Serb minority in Kosovo. Although most of it looked organized while designing policy papers and legislation for education, in fact, the main action was missing. This action had to be followed by the international community. International community under the UNMIK administration was focused mostly on designing policy papers in cooperation with the local authorities but it never had the right approach to the problem. The core of the problem that many internationals in Kosovo never understood was how Albanians thought they were perceived from Serbs (and visa versa) because this had a significant influence on how both sides came to understand themselves who they are. The process of identity formation involves dialogic negotiation with others and this is what was lacking for many years after the war.

For instance UNMIK never used the educational institutions and schools in order to support youths' development toward a positive sense of ethnic identity by organizing several programs that can build up their sense of interaction among the ethnicities improving their understanding on other ethnicities. If students from both sides were allowed for the minimum interaction they would have better understanding of the ethnic identity, they would become more tolerate and respect on other ethnic groups. Instead, under UNMIK the separation/traditional type of education isolated from the mainstream society was allowed to be established among the Serbian community and the concept of the multiethnic Kosovo in fact it was only a farce promoted in the bill-boards all over Kosovo.

Identity is negotiated between the people who live in the same space and recognition from others as they develop their own identity is very significant. Modern democratic societies are characterized by the increased importance of recognition. As such, recognition has become increasingly significant for the development of self identity and the recognition of others has gained a new importance for our modem identity. As a result, in our modem society misrecognition or lack of recognition during the process of negotiation can mean oppression. Misrecognition means denial of one's worth as a human being and this is likely to result in lack of self-esteem (Taylor, 1994).

More concretely, today's misrecognition between Albanian and Serb youngsters is exclusively a product of the wrong approach of the international community applied while building and developing the education system in Kosovo after the war of 1998-1999. International community in Kosovo without some thorough analyses and in attempt to respect individuals equally, regardless of their cultural particularities have applied the so-called difference-blinded approach where collective differences have been treated as if they did not exist. With this approach, equal respect means that individuals are treated exactly the same way, universally meaning same rights as anyone else, regardless of race, religion, or gender. The principle of this recognition is very simple: an equal treatment regardless of cultural and social differences (Taylor, 1995). Kymlicka recognizes the significance of culture for developing our sense of self. He argues that cultural membership has a considerable significance for achieving the sense of belonging to a cultural structure and history (Kyrnlicka, 1989).

The institutional design of Kosovo as civic and multiethnic state with elements of individual liberalism where all of its individual citizens are equal before the law (Albanians, Serbs, Turks, Roma, etc) to some degree referred to the Christian Joppke's concept of citizenship as rights and as identity somehow was introduced in Kosovo's case ( Jopke, 2007). The problem though relies on the fact that universal legal rights of citizenship were offered only through the official policies, papers, strategies and finally in the constitution. In other words through the difference-blinded approach which may work 
well in societies where there are no cultural differences but in cases like Kosovo it continued to produce misrecognition between younger generations from both sides. Misrecognition as a concept incarnated in the education system established after the WWII survives these days as in both curricula that of Kosovo (implemented by the majority of Albanians) and Serbia (implemented in Kosovo by local Serbian minority) younger generations continue to be educated in the spirit of nationalism by demonizing the other side. Mainly youngsters from both sides are taught that their race is superior compared to the other and that is why ethnocentrism is present in every aspect of public life. Consequently, Serbs continue to reject the state of Kosovo creating the stateness problem in the territories where they live, while the majority of Albanians contribute to the contested statehood of Kosovo by refusing its civic and multiethnic character.

As a result, tension between civic and multicultural concept of citizenship on one side, and ethno-national concept on the other side is high as a number of people question the legitimacy of the state of Kosovo as a new polity.

The situation wouldn't be different if Albanians and Serbs would be asked for instance to design the character of the new Kosovo's state symbols, as one option would be the Serbian nationalist royalist flag with two dangerous looking white eagles on black background and the other option would be the double black headed eagle on the red background. Still,excluding the minimum cultural particularities while offering to establish a citizenship regime undermines the consolidation of Kosovo's civic and multiethnic state itself. Today in 'civic and multiethnic' state of Kosovo, for instance ethnic Serbian schools (tolerated and supported from UNMIK) continue to enhance a social life segregated from Kosovo by developing strong political ties with Serbia. Segregated education influences the formation of national and ethnic identity among new generations, interlinked with Albania and Serbia. This kind of political climate is not in favor of the future Kosovo's EU perspective as long as out there we have thousands of young Albanians and Serbs waiting for their moment in history to show all possible hatred out of their ultranationalist kitchens that has fed them for years within the two segregated systems of education. Segregated system of education in Kosovo will continue to shape the personality of the youth by cultivating their national and ethnic identity and the sense of belonging to the nation before providing educational skills and knowledge for the potential labor markets of the future.

As both ethnic and national identities play important roles in guiding political behavior it is important for Serbs to struggle to maintain ethnic identity and culture but by trying models of coexistence with the dominant culture in Kosovo. The integration of bicultural type that speaks both languages and is accepted by the mainstream society, without losing the tie to their cultural community is the best model for Serbs of Kosovo to be considered. On the other side Kosovo's institution especially Ministry of Education must endeavor to start a public dialogue through which cultural particularities of the other side should be recognized publicly and within the context of school curriculums. Although this sounds way to utopist it is the only hope that one day in the future Serbs could be integrated into Kosovo's education system by simultaneously recognizing the cultural particularities of the dominant group. Otherwise such a situation is nothing more or less than what the constitution of Kosovo and criteria's for EU integration require. This remains the only solution in lack of clear strategy from the Kosovo Government to attract and integrate Kosovo Serbs through economy, an offer that wouldn't be rejected because social welfare is always a better option rather than the option of cheering ultranationalist songs with the empty stomach. As long as we have this level of corruption in Kosovo this is equally an utopist option and it is not imaginable to see such a vision to be implemented from Kosovo Government. Thus having such weak starting positions due to the high degree of corruption the government of Kosovo is one of the rare governments in Europe that negotiates the rights of its citizens ( in this case of Kosovo Serbs ) with another state (in this case with Serbia).

Education is one of the strongest means of bringing about a change in society. It is considered to be the foundation of society as it brings social prosperity and political stability. Good education helps contribute to the development of good human beings, which is why education is a major aspect of any developing society. In attempting to realize an ideal multicultural society intercultural understanding is very important. Although it is hard to be achieved it is not impossible if engaged dialogue can be promoted in classrooms by introducing various perspectives on a controversial issues to students from both communities. It remains to be seen if Kosovo institutions will succeed to change the role of education in the "postnational" era. On the other side, in a world of global markets and supranational political organizations only time will show how distinctive will national education systems of Kosovo and Serbia will remain against pressures for international convergence.

One thing is for sure that with current attitudes Kosovo can be defined as a state with institutionalized civic identity but hidden behind the uniform of nationalist and ethnic identities always threatening with death to the Kosovan citizenship and keeping Kosovo's statehood unfinished. 


\section{References}

[1] Bassler, Terrice (2005) Learning to Change: The Experience of Transforming Education in South East Europe, Central European University Press, Budapest, New York

[2] Bieber, Florian and Daskalovski, Židas (2003): Understanding the War in Kosovo, Routledge, New York.

[3] Christian, Jopke (2007) Transformation of Citizenship: Status, Rights, Identity, Citizenship Studies, Vol.11.No.1. (February 2007) pp37-39

[4] Clark, Howard (2000): Civil Resistance in Kosovo, Pluto Press, London

[5] Jano, Dorian (2008) From 'Balkanization' to 'Europeanization': The Stages of Western Balkans Complex Transformations, Centre international de formation européenne.

[6] KHDR (2008): Kosovo Human Development Report, "Civil Society and Development", Prishtina, p 36-39,

[7] Kostovicova, Denisa (2005) Kosovo: The Politics of Identity and Space, Published by Routledge, 2005, page 38

[8] Kymlicka, Will (1989) Liberalism, community and culture, Oxford, England \& New York: Oxford University Press

[9] Lukic, Reneo (1996): Europe from the Balkans to the Urals: The Disintegration of Yugoslavia and the Soviet Union, Stockholm International Peace Research Institute, Contributor Allen Lynch, Oxford University Press, Oxford

[10] Mertus, Julie (1999): How Myths and Truths Started a War, University of California Press, and Los Angeles

[11] Schwandner -Sievers Stephanie and Jurgen Fischer, Bernd (2002): Albanian Identities-Myth and History, Indiana University Press, Bloomington

[12] Sell, Louis (2003): Slobodan Milosevic and the Destruction of Yugoslavia, Duke University Press, and Durham

[13] Taylor, Charles (1994) "The politics of recognition" in A. Gutmann (Ed.), "Multiculturalism: Examining the politics of recognition". Princeton, NJ: Princeton, University Press.

[14] Waller, Michael, Drezov Kyril, Gökay Bülent (2001): Kosovo the Politics of Delusion, Frank Cass Publishers, London

[15] Weller, Marc (2009) Contested Statehood: Kosovo's Struggle for Independence, OUP Oxford, 2009. 